\title{
RACHUNKOWOŚĆ JAKO ŹRÓDŁO INFORMACJI O KOSZTACH W PROCESIE ZARZĄDZANIA JEDNOSTKĄ SAMORZĄDU TERYTORIALNEGO
}

Z ary s treści. Stopniowa zmiana systemu zarządzania jednostkami samorządu terytorialnego powoduje wzrost potrzeb informacyjnych generowanych przez rachunkowość. Oczekuje się od niej jednoznacznego określenia kryteriów identyfikacji, pomiaru, klasyfikacji i grupowania zasobów kontrolowanych i konsumowanych przez jednostki samorządu terytorialnego. Celem tego jest umożliwienie efektywnego zarządzania sektorem publicznym i dopełnienie obowiązków wynikających z zastosowania zasady memoriałowej w ewidencji księgowej. Według tej zasady podstawą oceny skuteczności prowadzonej gospodarki finansowej jest ujmowanie w księgach rachunkowych kosztów związanych z realizacją danego zadania budżetowego w okresach, w których one faktycznie zostały poniesione, a nie w momencie przekazania środków finansowych na dany tytuł wydatkowania.

Słow a kluczowe: rachunkowość, informacja, zasada memoriałowa, koszt.

\section{WSTEPP}

Postępujący rozwój gospodarki rynkowej, decentralizacja władzy państwowej polegająca na przekazywaniu części zadań publicznych samorządom oraz 
stopniowa ewolucja systemu zarządzania sektorem publicznym polegająca na wdrożeniu Zasad Nowego Zarządzania Publicznego wpływają na wzrost potrzeb informacyjnych zgłaszanych wobec rachunkowości. Nowe wymagania stawiane przed rachunkowością sektora budżetowego wymuszają klarowne i jednoznaczne określenie kryteriów identyfikacji, pomiaru, klasyfikacji i grupowania zasobów kontrolowanych i konsumowanych przez jednostki tego sektora. Ma to z jednej strony umożliwić efektywne zarządzanie sektorem publicznym, a z drugiej strony dopełnić obowiązków wynikających z opartych na zasadzie memoriałowej nowoczesnych systemów rachunkowości.

Celem niniejszego opracowania jest próba identyfikacji obszarów rachunkowości jednostek samorządu terytorialnego, w których należałoby wprowadzić zmiany, aby informacje z niej płynące były w pełni przydatne w procesie nowego zarządzania co w konsekwencji wpłynie na bardziej efektywne wykorzystanie zasobów.

\section{POJĘCIE I ISTOTA KOSZTÓW W PROCESIE ZARZĄDZANIA JEDNOSTKĄ SAMORZĄDU TERYTORIALNEGO}

Jednostki samorządu terytorialnego mają za zadanie zaspokajać potrzeby mieszkańców zamieszkujących teren ich wspólnoty. Aby to zrealizować, wykorzystują szeroką gamę usług publicznych, do świadczenia, których potrzebne są im różne zasoby i umiejętności. Ich różnorodność oraz niepowtarzalność powoduje, że są one wyróżnikiem organizacji, a jednocześnie determinują skuteczność i sprawność jej działania. Posiadanie i wykorzystanie odpowiedniego zbioru czynników wytwórczych, które przekształcane są w odpowiednie dobra i usługi, stanowi podstawę sprawnego funkcjonowania każdej organizacji.

Zapewnienie potencjału rozwojowego ${ }^{1}$ niezbędnego do osiągnięcia głównych celów organizacji wymaga wyposażenia ich w odpowiednie środki finansowe. Powoduje to zmianę spojrzenia na główne zadania realizowane w organizacji, do których należy zaliczyć w szczególności maksymalizację wartości przyszłych wpływów pieniężnych netto, lub bardziej precyzyjnie - wartości bieżącej przyszłych wpływów pieniężnych (Drury, 2002, s. 25). W jednostkach samorządu terytorialnego wpłynie to na poprawę jakości i asortymen-

1 Możliwości, zdolności i użyteczności zawarte w posiadanych zasobach, a także umiejętne korzystanie z zasobów otoczenia. 
tu świadczonych usług publicznych. Jest to niezwykle istotne gdyż potrzeby społeczeństwa są nieograniczone, ciągle się zmieniają i muszą być zaspokajane nieprzerwanie (Flejterski, Panasiuk, Perenc, Rosa, 2005, s. 452).

Istotnym zagadnieniem $\mathrm{w}$ każdej organizacji, $\mathrm{w}$ tym również samorządowej, jest proces ustalania kosztów realizacji zadań i związanych z nimi wydatków. Punktem wyjścia dla zamierzeń opisanych w planach, jako rezultaty działań powinny być cechy i funkcje realizowanych usług, które zaspokoją potrzeby wspólnoty. Wskażą one bowiem zasoby, jakie powinny zostać zużyte, oraz sposoby, jak należy je powiązać, by osiągnięte rezultaty w jak najlepszy sposób zaspokajały określone potrzeby. Przeprowadzone badania oczekiwań oraz ich analiza dadzą informacje o zużyciu zasobów będących w dyspozycji jednostki, czyli o wysokości kosztów własnych. Koszty te stanowią wyrażone w pieniądzu celowe zużycie czynników produkcji oraz niektóre wydatki niestanowiące ich zużycia (np. ubezpieczenia, podatki, opłaty, a w przypadku JST również udzielone dotacje lub inne świadczenia finansowane z budżetu), których efektem jest użyteczny produkt lub usługa.

Koszty to kategoria ekonomiczna, której przypisuje się charakter pierwotności względem uzyskiwanych efektów. Powoduje to, że są one podstawą procesów informacyjno-decyzyjnych we wszystkich organizacjach, niezależnie od celu, jaki chcą zrealizować. Wysokość kosztów w JST jest odpowiedzią na pytanie, czy wytworzenie pewnej liczby usług publicznych o określonym poziomie społecznej korzystności stanowi w oczach społeczności usprawiedliwienie dla zużycia ograniczonych zasobów. Podejmując określoną działalność, organizacja winna zatem rozważać również koszty utraconych korzyści (Obłój, 2000, s. 25-26), które wyrażają niezrealizowane efekty z innych możliwych do uzyskania przy wykorzystaniu tych samych zasobów działań. Prowadzi to do obowiązku wykorzystywania w ocenie efektywności prowadzonej działalności porównań ponoszonych kosztów nie tylko z osiąganymi efektami, ale również z kosztami utraconych możliwości. Jest to szczególnie ważne w organizacjach publicznych, w których istnieją znaczne trudności z pomiarem uzyskiwanych efektów.

Od pojęcia koszt należy odróżnić pojęcie wydatek. Wydatek oznacza wszelkie zmniejszenia środków pieniężnych.

Informacje o wysokości ponoszonych kosztów mają podstawowe znaczenie dla zarządzania każdą organizacją. Wynika to z faktu, że w nich znajduje się odzwierciedlenie jakości pracy na wszelkich odcinkach działalności (Nowak, Piechota, Wierzbiński, 2004, s. 23).

Na podstawie przedstawionych wyżej zależności można stwierdzić, że koszty własne są związane z ponoszonymi wydatkami, choć nie wszystkie 
wydatki mają charakter kosztów - wynika to z faktu, że pojęcie „,wydatki” jest szersze od pojęcia „koszty”, gdyż charakter kosztów mają tylko te wydatki, które związane są ze zużyciem zasobów (np. nie są kosztami wydatki związane ze spłatą raty kredytu) (Gabrusewicz, Kamela-Sowińska, Poetschke, 2000, s. 47-48).

Kolejnym wnioskiem wnikającym z zależności pomiędzy pojęciem kosztu a wydatku jest to, że powstawanie kosztów własnych może być niezależne w czasie od dokonywania wydatków - zużycie zasobów jest ściśle powiązane z działalnością jednostki, a więc konkretnymi przedziałami czasowymi; zależność ta nie dotyczy czasu zapłaty (dokonania wydatku), co powoduje rozbieżności między momentem powstania kosztu i wydatku (Gabrusewicz, Kamela-Sowińska, Poetschke, 2000, s. 47-48).

Omawiana zależność wskazuje również, że wydatki nie są związane ze zużyciem zasobów, ale wycena ponoszonych kosztów opiera się z reguły na dokonywanych wydatkach - tym sposobem ustalenie kosztów poniesionych w związku z realizacją celów następuje przez wycenę zużytych zasobów, której dokonuje się zwykle na podstawie ceny nabycia (Gabrusewicz, Kamela-Sowińska, Poetschke, 2000, s. 47-48).

Specyficzny charakter jednostek samorządu terytorialnego powoduje, że w długim okresie zależność pomiędzy wpływami pieniężnym netto a uzyskiwanymi efektami z prowadzonej działalności powinna osiągnąć wartość równą zero. Jest to podstawa do oceny prawidłowości w relacji wydatki-koszty własne. Wymagane jest, by w długim okresie, wydatki ponoszone w toku realizacji określonego działania odpowiadały kosztom tego działania ${ }^{2}$. Jednocześnie przedstawiona definicja kosztów nakazuje między innymi, że dla zaliczenia wydatku do kosztów nieodzowne jest, by były one ponoszone celowo i dla uzyskania społecznie użytecznego efektu. Jeśli więc w ostatecznym rozrachunku przedstawiona równość zostanie zachwiana, to poniesionych wydatków nie można uznać za celowe lub w efekcie końcowym nie moż-

2 Relacja ta dotyczy tylko kosztów własnych i dlatego do kategorii wydatki zalicza się tylko te, które poniesiono ze środków własnych organizacji, np. nie można zaliczyć tu wydatków dokonywanych przy użyciu środków finansowych pochodzących z zaciągniętego kredytu, a za wydatki będą w takiej sytuacji uznane spłacane raty, które finansowane są z wypracowanych (pozyskanych) w toku działalności środków własnych (inne podejście spowodowałoby podwójne liczenie kwot wydatkowanych z kredytu na finansowanie działania i rat kredytu spłacanych właścicielowi kapitału). Rozbieżności mogą również powstać, gdy w realizacji działań wykorzystane zostaną czynniki produkcji otrzymane nieodpłatnie (brak wydatku), ale ich oceny można dokonać na postawie analizy odchyleń pomiędzy wydatkami i kosztami. 
na doszukać się użyteczności (odpowiedniego poziomu zaspokojenia potrzeb ludzkich) zrealizowanych usług. Tego typu wydatki sklasyfikować należy jako straty, a ich występowanie będzie wskaźnikiem braku racjonalności działania jednostek samorządu terytorialnego oraz pozwoli ocenić jakość planowania działań w tych jednostkach.

\section{RACHUNKOWOŚĆ JAKO SYSTEM INFORMACYJNY}

$\mathrm{Z}$ analizy definicji rachunkowości formułowanych przez różnych autorów wynika, że jest ona procesem ciągłej identyfikacji, pomiaru, klasyfikacji, grupowania, rejestracji i prezentacji informacji w mierniku pieniężnym dla szerokiego zakresu celów informacyjnych i kontrolnych, ustalania i planowania wyników działania, stanu posiadanych zasobów i źródeł ich finansowania oraz sporządzania różnego rodzaju sprawozdań (Sawicki, 2002, s. 18; Hendriksen, van Berda, 2002, s. 1; Winiarska, 2000, s. 34). Przedmiotem rachunkowości są zjawiska i procesy gospodarcze związane $\mathrm{z}$ ruchem i finansowaniem środków, podmiotem zaś wszystkie jednostki prowadzące rachunkowość, które zostały wyodrębnione majątkowo, a powierzony im majątek osób prawnych bądź fizycznych stanowi materialną podstawę ich działalności. Informacje dostarczane przez rachunkowość umożliwiają syntetyczne wyrażenie stopnia realizacji celów oraz efektów działalności jednostek gospodarczych, są więc ważnym elementem zarządzania. Zadaniem rachunkowości jest przetwarzanie pierwotnych danych księgowych w postaci nieuporządkowanego zbioru liczb w informacje ekonomiczne wykorzystywane przez odbiorców wewnętrznych w procesie zarządzania, jak również przez odbiorców zewnętrznych zajmujących się oceną kondycji finansowej jednostki gospodarczej.

Rachunkowość jest jedna, lecz ze względu na szeroki zakres jednostek zobligowanych do jej prowadzania wyodrębnia się dla celów praktyki gospodarczej różne jej typy. Dlatego też w przypadku jednostek funkcjonujących w ramach finansów publicznych można mówić o rachunkowości budżetowej.

Według Leksykonu rachunkowości rachunkowość budżetowa obejmuje rachunkowość rządu, samorządów lokalnych i instytucji budżetowych. Jej zadaniem jest dostarczenie informacji o wykonaniu budżetu, a także planów finansowych i sytuacji majątkowej jednostek budżetowych (Nowak, 1996, s. 175).

Cechą charakterystyczną omawianego rodzaju rachunkowości jest to, że opiera się ona na zasadzie kasowej. Ujęcie kasowe w jednostkach samorządu terytorialnego dotyczy ewidencji dochodów i wydatków budżetowych i wynika z dwóch aktów prawnych: 
- Ustawy o finansach publicznych, która nakazuje, aby dochody i wydatki ujmowane były w terminie ich zapłaty, niezależnie od rocznego budżetu, którego dotyczą (Ustawa o finansach publicznych, 2009);

- Rozporządzenia Ministra Finansów w sprawie szczegółowych zasad rachunkowości oraz planów kont dla budżetu państwa, budżetów jednostek samorządu terytorialnego oraz niektórych jednostek sektora finansów publicznych.

W rachunkowości prowadzonej według zasady kasowej podstawowymi kategoriami są przepływy środków pieniężnych. W tym ujęciu transakcje i zdarzenia ujmowane są w księgach niezależnie od momentu realizacji umowy, tylko wtedy, gdy następuje faktyczny wpływ środków pieniężnych na rachunek bankowy lub ich wypłata. Konsekwencją tego może być zaksięgowanie dochodów i wydatków budżetowych w innym roku obrachunkowym niż ten, którego dotyczą. Przy zastosowaniu tej metody podstawowym problemem jest posiadanie odpowiedniej ilości środków pieniężnych w określonym czasie, ich wydatkowanie zgodnie z paragrafem i we właściwej ilości, a nie zadanie, na które środki finansowe zostały przeznaczone. Ujęcie to nie sprzyja analizie skuteczności realizacji zadań wykonywanych przez JST (Filipiak, 2009, s. 149).

Kolejną niedoskonałością stosowania zasady kasowej w rachunkowości jednostek samorządu terytorialnego jest brak konieczności tworzenia rezerw na należności i zobowiązania. Może to wpływać na wiarygodność poziomu nadwyżki bądź deficytu budżetowego na skutek przyspieszenia lub opóźnienia regulowania płatności. Nieujmowanie, jako wydatków budżetowych zobowiązań, które powstały w wyniku zakupionych i otrzymanych towarów i usług, wpływa na zaniżenie rzeczywistego deficytu budżetowego (Winiarska, Kaczurak-Kozak, 2010, s. 34). Istnienie potencjalnej możliwości kreowania wyniku budżetu obniża racjonalne zarządzanie środkami przeznaczonymi na wydatki danego roku.

Zaletą stosowania ujęcia kasowego jest możliwość szybkiej oceny gospodarowania środkami pieniężnymi i dokonywania porównań z ustalonymi wcześniej wielkościami. Zalety i wady zasady kasowej przedstawia tabela 1.

Jak wspomniano wcześniej, najważniejsze dla właściwego podejmowania decyzji zarządczych są informacje dotyczące kosztów funkcjonowania jednostki. Bez ich ponoszenia nie jest możliwe przeprowadzenie jakichkolwiek działań gospodarczych. W rachunkowości budżetowej prowadzonej według zasady kasowej nie ma możliwości skalkulowania kosztów świadczonych usług, a nawet ogólnych kosztów operacyjnych jednostki. W księgach ujmowane są płatności fizycznie wykonane niezależnie od tego, czy dotyczyły one 
kosztów tego roku. Ponadto wydatki inwestycyjne są traktowane w taki sam sposób, jak wydatki dotyczące kosztów zatrudnienia, bez względu na fakt, że są one produktywne przez wiele lat. Konsekwencją tego jest brak bodźców do efektywnego wykorzystania majątku trwałego. Niekapitalizowanie aktywów trwałych oraz niewykazywanie zobowiązań długoterminowych powoduje, że nie można rzetelnie i wiarygodnie przedstawić kosztów działalności operacyjnej w danym okresie sprawozdawczym (Zysnarska, 2010, s. 37).

Tabela 1. Zalety i wady rachunkowości według zasady kasowej

\begin{tabular}{|l|l|}
\hline \multicolumn{1}{|c|}{ Zalety } & Wady \\
\hline - koherencyjność z kasowym sposobem & - wąski zakres informacji obejmujący wy- \\
budżetowania, & łącznie przepływy pieniężne i stan gotówki, \\
- prostota i porównywalność informacji & - możliwość kreowania wyniku wykonania \\
pieniężnych, & budżetu, \\
- gwarancja sprawnego monitorowania & - brak informacji dla racjonalnego zarządza- \\
i kontroli wykonania budżetu & nia zasobami publicznymi, \\
& - niedoinformowanie społeczeństwa o fak- \\
& tycznym zadłużeniu \\
\hline
\end{tabular}

Źródło: opracowanie własne na podstawie: Zysnarska, 2010, s. 39.

Rozporządzenie Ministra Finansów z dnia 28 lipca 2006 w sprawie szczegółowych zasad rachunkowości oraz planów kont dla budżetu państwa, budżetów jednostek samorządu terytorialnego oraz niektórych jednostek sektora finansów publicznych nakłada na jednostki samorządu terytorialnego obowiązek sporządzania Rachunku zysków i strat w wariancie porównawczym. Konsekwencją tego jest konieczność ewidencji przez te jednostki kosztów w układzie rodzajowym. Koszty według rodzaju ujęte są w zespole 4 planu kont i służą do ewidencji kosztów prostych według rodzajów oraz do ich rozliczania na kontach zespołu 5. Na kontach tego zespołu księguje się wyłącznie koszty operacyjne. Zgodnie z cytowanym już Rozporządzeniem Ministra Finansów w JST wyróżnia się takie konta syntetyczne zespołu 4, jak: Koszty według rodzaju, Amortyzacja, Rozliczenie kosztów.

Układ rodzajowy kosztów pozwala na uzyskanie informacji o wielkości sumarycznego zużycia $\mathrm{w}$ danym okresie czynników produkcji w przekroju prostych, jednorodnych i niepodzielnych kosztów.

Ewidencja kosztów według rodzaju jest wystarczająca dla potrzeb sprawozdawczości, lecz dla właściwego podejmowania decyzji zarządczych wewnątrz JST jest zbyt zagregowana. Wpływa to na zwiększenie możliwości popełnienia błędu w budżetowaniu kosztów i mniejszą efektywność systemu 
dostarczania informacji. Aby zapobiec takim sytuacjom, postuluje się odstąpienie od ewidencji kosztów w układzie rodzajowym na rzecz takich systemów, które lepiej posłużą procesowi zarządzania. Jednym z nich może być kalkulacyjny układ ewidencji kosztów, który dostarczy odpowiedzi na pytania, na co zostały poniesione koszty w poszczególnych pozycjach. Układ ten opiera się na podziale kosztów na bezpośrednie i pośrednie i pozwala odpowiedzieć na pytanie, jaki jest jednostkowy koszt własny produktów i usług oraz jaka jest struktura kosztów ponoszonych przez JST.

Reasumując przedstawione rozważania nt. metody kasowej wykorzystywanej w rachunkowości budżetowej, można stwierdzić, że to ujęcie generuje zbyt wąski zakres informacji związanych z ruchem i stanem aktywów pieniężnych w danym okresie sprawozdawczym, nie dostarcza informacji o kosztach działalności i związanych z nimi zobowiązaniach. Ujęcie to uniemożliwia otrzymanie pełnej informacji finansowej istotnej z punktu widzenia podejmowania decyzji i odpowiedzialności za zarządzanie zasobami publicznymi.

\section{PROPOZYCJE ZMIAN W RACHUNKOWOŚCI BUDŻETOWEJ}

W związku z częściowo omówionymi wcześniej dysfunkcjami systemu rachunkowości budżetowej należy dążyć do stworzenia docelowego systemu ewidencji budżetowej, który umożliwiłby równoległe śledzenie ruchu pieniądza i zadania, na które dane środki były przekazane. Wpłynęłoby to na zwiększenie skuteczności realizacji zadań publicznych. Może się to dokonać przez przejście $z$ ewidencji opartej na zasadzie kasowej na rzecz ewidencji według zasady memoriałowej. Ujmowanie w księgach rachunkowych kosztów związanych z realizacją danego zadania budżetowego w okresach, w których one faktycznie zostały poniesione, a nie w momencie przekazania środków finansowych na dany tytuł wydatkowania, stanie się podstawą oceny skuteczności prowadzonej gospodarki finansowej.

Zasada memoriałowa oraz związane z nią ukierunkowanie na zużycie zasobów, planowanie na podstawie zużycia zasobów ma szczególne znaczenie w odniesieniu do planowania zadaniowego JST. Znajduje to uzasadnienie w możliwości określenia funkcji i cech realizowanych usług publicznych, które zaspokoją potrzeby mieszkańców, a jednocześnie pozwoli na wskazanie takiej kompilacji zasobów, które w sposób efektywny zrealizują ten cel jednostki. W odniesieniu bowiem do zjawiska konkurencji, dynamiki wymagań klientów i ciągłych zmian w otoczeniu organizacji oraz ograniczoności 
możliwych do wykorzystania środków publicznych ważne jest poszukiwanie kompromisu między jakością i funkcjonalnością efektów działania a kosztem ich wytworzenia. Jednostki samorządu terytorialnego zobligowane są więc - podobnie jak inne organizacje, również komercyjne - do obniżania kosztów własnych przy jednoczesnym doskonaleniu jakości wyrobów i usług. Te zależności powodują, że podstawowe działania planistyczne w skali mikro (Wernik, 2007, s. 75-76) powinny dokonywać się w powiązaniu z zasadą memoriałową, a wynikające $\mathrm{z}$ obowiązku zachowania dyscypliny budżetowej stosowanie zasady kasowej musi być traktowane, jako uzupełnienie i dodatkowy obowiązek jednostek sektora publicznego.

Chociaż rachunkowość oparta na zasadzie kasowej nie generuje informacji potrzebnych $\mathrm{w}$ procesie podejmowania decyzji oraz wyceny rezultatów działalności czy egzekwowania odpowiedzialności za powierzone zasoby, to służy interesowi sprawujących rządy, umożliwiając kreowanie odpowiedniego wizerunku prowadzonej przez nich polityki finansowej. To może uzasadniać brak politycznej woli wdrożenia bardziej efektywnego informacyjnie modelu rachunkowości (Zysnarska, 2010, s. 35).

Dodatkowym czynnikiem sprzyjającym utrzymywaniu się omawianego systemu rachunkowości jest opór ze strony pracowników samorządowych przed jakimikolwiek zmianami. Nie są oni motywowani do skuteczniejszego działania, ponieważ każda wprowadzana zmiana kojarzona jest z nowymi obowiązkami, dodatkową pracą bez dodatkowego ekwiwalentu.

Na wprowadzenie zasady memoriałowej w jednostkach samorządu terytorialnego w Polsce wpływ będą miały wymagania dotyczące przygotowania oraz prezentacji informacji finansowej i statystycznej, wynikające z Systemu Rachunków Narodowych (SNA 93) oraz Systemu Rachunków Europejskich 95 (ESA 95). SNA 93 obowiązuje wszystkie kraje w gospodarce rynkowej, ESA 95 zaś dodatkowo kraje członkowskie UE.

Kolejnym krokiem mającym przyczynić się do zwiększenia użyteczności informacji płynących z sytemu rachunkowości budżetowej jest rozbudowa systemów ewidencji kosztów. Jest to proces bardzo kosztowny i mogący napotkać w JST wiele barier wynikających ze specyfiki ich finansowania. Ograniczoność środków finansowych wymaga działań, które przyniosą odpowiednie efekty, a jednocześnie nie stanowią znacznego obciążenia finansowego jednostek. Takim rozwiązaniem może być analityczna struktura kosztów według rodzaju, w której dokonano by rozbudowy struktury kosztów rodzajowych, tak by lepiej służyła procesowi podejmowania decyzji.

Wprowadzenie kalkulacyjnego układu ewidencji kosztów i wykorzystywanych w nim rozwiązań ewidencyjnych mogłoby się również przyczynić do 
uzyskania szczegółowej informacji niezbędnej do prawidłowego podejmowania decyzji zarządczych. Można byłoby wyróżnić ośrodki odpowiedzialności, którym przydzielone zostały zadania i środki na ich realizację, a odpowiedzialność za tę działalność przypisać wskazanej i posiadającej odpowiednie kwalifikacje osobie. Doprowadziłoby to do uzyskania informacji o kosztach funkcji zaopatrzenia, produkcji, zbytu i zarządu.

Konieczność uzyskiwania coraz to bardziej szczegółowych informacji płynących z rachunkowości budżetowej wynika również ze zmian, jakie nadchodzą przy sporządzaniu budżetów JST. Wymogi wspominanego Nowoczesnego Zarządzania Publicznego postulują, aby odchodzić od budżetów liniowych na rzecz budżetów zadaniowych. Podstawą planów finansowych JST sporządzanych w tym układzie jest wskazanie dla konkretnych zadań osób odpowiedzialnych za nie i przypisanie większego znaczenia efektywności prowadzonych zadań. Wszystko to wymagać będzie pełniejszego i dokładniejszego systemu rachunkowości. Zmiany, jakie zachodzą w zarządzaniu JST, powodują potrzebę sprowadzenia ich działalności do realizacji poszczególnych zasad. Z tego powodu słuszne wydaje się dalsze rozbudowanie systemu rachunkowości z uwzględnieniem wymagań rachunkowości zarządczej.

Nowe rozwiązania rachunkowości jednostek samorządu terytorialnego nie mogą więc prowadzić do zastępowania układu rodzajowego czy kalkulacyjnego (w rozwiązaniu tradycyjnym) nową strukturą służącą grupowaniu i analizie kosztów - układem kosztów działań w organizacji. Powinien on zostać wprowadzony jako dodatkowy układ analityczny kosztów. Możliwym efektem będzie też zastosowanie rachunku kosztów standardowych, który wykorzysta informacje o poziomie i kierunku odchyleń generowanych na kontach zespołu 5. Znacznym usprawnieniem może też być wykorzystanie nośników kosztów dla rozliczania usług świadczonych przez poszczególne jednostki wewnętrzne na rzecz pozostałych części JST.

Wskazane rozwiązania nie stanowią zaprzeczenia wymaganiom prawnym, które nakazują stosowanie rozwiązań służących ustaleniu rzetelnego obrazu kosztów i efektów we wszystkich podmiotach gospodarki.

\section{PODSUMOWANIE}

Wraz z rozwojem gospodarki rynkowej, a przede wszystkim decentralizacją władzy państwowej i umacnianiem się lokalnej samorządności spowodowanej nowymi wzorcami zarządzania przed rachunkowością postawiono nowe cele, związane $\mathrm{z}$ realizacją zadań, pomiarem rezultatów działań. Zmiana 
sposobu zarządzania sektorem publicznym wywołała ostrą krytykę modelu kasowego rachunkowości, według którego transakcje, zdarzenia związane z gromadzeniem dochodów i dokonywaniem wydatków budżetowych ujmowane są z chwilą zmiany salda na rachunku budżetowym, a podstawowymi kategoriami sprawozdawczymi są przepływy środków pieniężnych oraz ich stan na początek i koniec okresu sprawozdawczego. Pojawiły się postulaty zastąpienia zasady kasowej rachunkowości budżetowej zasadą memoriałową, która zapewnia znacznie pełniejszą informację sprawozdawczą.

Zadania stojące przed rachunkowością jednostek samorządu terytorialnego wymagać będą szeregu czasochłonnych i kosztownych zmian. W szczególności dotyczy to zapewnienia odpowiedniej ilości środków służących zatrudnieniu, potrafiącej wprowadzić wskazane usprawnienia kadry. Jednocześnie też, zarządzający tymi jednostkami muszą uzmysłowić sobie potrzebę tych przeobrażeń oraz korzyści z nich wynikające.

\section{LITERATURA}

Drury C. (2002), Rachunek kosztów, Wydawnictwo Naukowe PWN, Warszawa.

Filipiak B., (2009), Metodyka kompleksowej oceny gospodarki finansowej jednostki samorzadu terytorialnego, DIFIN, Warszawa.

Hendriksen E.A., van Berda M.F. (2002), Teoria rachunkowości, Wydawnictwo Naukowe PWN, Warszawa.

Lichtarski J. (2005), Podstawy nauki o przedsiębiorstwie, Wydawnictwo Akademii Ekonomicznej we Wrocławiu, Wrocław.

Nowak E. (1996), Leksykon rachunkowości, PWN, Warszawa.

Nowak E., Piechota R., Wierzbiński M. (2004), Rachunek kosztów w zarządzaniu przedsiębiorstwem, PWE, Warszawa.

Obłój K. (2000), Strategia sukcesu firmy, PWE, Warszawa.

Sawicki K. (red.) (2001), Podstawy rachunkowości, PWE, Warszawa.

Winiarska K. (2000), Rachunkowość przedsiębiorstw w procesie integracji z UE, Wyższa Szkoła Integracji Europejskiej, Szczecin.

Winiarska K, Kaczurak-Kozak M. (2010), Rachunkowość budżetowa, Oficyna a Wolters Kluwer business.

Zysnarska A. (2010), Rachunkowość budżetowa w świetle koncepcji prawdziwego i wiernego obrazu, Wydawnictwo Uniwersytetu Gdańskiego, Gdańsk. 


\title{
ACCOUNTING AS A SOURCE OF INFORMATION OF COSTS IN THE MANAGEMENT OF THE LOCAL GOVERMMENT UNIT
}

\begin{abstract}
A b stract. Gradual changes in the management of local government units increase the need for information generated by the accounting. It should clearly define the criteria for the identification, measurement, classification and grouping the resources that are controlled and consumed by local government units. The purposes of this are: to enable effective management of public sector and to fulfill the obligations arising from the application of accrual accounting principle. According to this principle the basis for the assessment of the effectiveness of financial management is the presentation of costs associated with the implementation of the tasks of the budget in the periods in which they are actually incurred, and not during the transfer of funds to spend.
\end{abstract}

K e y w o rd s: accounting, information, accrual-based accounting, cost. 